\section{Anomalía de Ebstein y síndrome de QT largo congénito. A propósito de un caso}

\section{Ebstein anomaly and congenital long QT syndrome. Report of a case}

La anomalía de Ebstein es una cardiopatía congénita que afecta principalmente la válvula tricúspide y se caracteriza por grados variables de displasia y adosamiento valvular ${ }^{1}$. Frecuentemente se asocia con anormalidades de la conducción atrio ventricular y la presencia de vías accesorias. No hay descripciones acerca del alargamiento de la fase de repolarización ventricular del potencial de acción en la anomalía de Ebstein y, por consiguiente, del síndrome de QT largo congénito.

Presentamos el caso de una paciente de 15 años de edad con anomalía de Ebstein, con adosamiento del 55\% de la valva anterior y septal (tipo B de la clasificación de Carpentier $^{1}$ ) y sordera bilateral congénita, diagnosticadas en el primer año de vida. A la edad de 14 años presenta un primer episodio sincopal en reposo. En el electrocardiograma se evidenció bloqueo aurículo-ventricular de primer grado e intervalo QT corregido con fórmula de Bazett de
$473 \mathrm{~ms}$ (fig. 1). El Holter mostró ritmo sinusal de base que conduce con bloqueo aurículo-ventricular de primer grado y que alterna con ritmo nodal, frecuencia cardiaca mínima de $48 \mathrm{lpm}$ e intervalo QTc prolongado de $480 \mathrm{~ms}$. Se inicia tratamiento con propranolol, previo a la realización de la prueba de esfuerzo.

Se realizó prueba de esfuerzo con protocolo de Bruce modificado, así como prueba de Viskin para síndrome de QT largo. En el electrocardiograma se identificó ritmo sinusal de base con frecuencia cardiaca de $72 \mathrm{lpm}$, QT medido de $400 \mathrm{~ms}$, QTc de $438 \mathrm{~ms}$ e intervalo R-R de $882 \mathrm{~ms}$. En la prueba de Viskin, durante la bipedestación, presentó frecuencia cardiaca de $68 \mathrm{lpm}$ con QT medido de $460 \mathrm{~ms}$, QTc de $489 \mathrm{~ms}$ e intervalo R-R de $882 \mathrm{~ms}$, acompañado de ondas $T$ con patrón bifásico en «silla de montar» con base amplia, característico de SQTL tipo 2 electrocardiográfico (figs. 2 A y 2 B).

La asociación de síndromes como lo son la anomalía de Ebstein y el síndrome de QT largo es extremadamente rara. En la literatura podría nombrase un solo caso de una paciente de 19 años con anomalía de Ebstein, síndrome de Wolff-Parkinson-White y síndrome de QT largo intermitente asociado al uso del amiodarona. El intervalo QT se mantuvo prolongado en esta paciente de forma intermitente, incluso después de la suspensión de

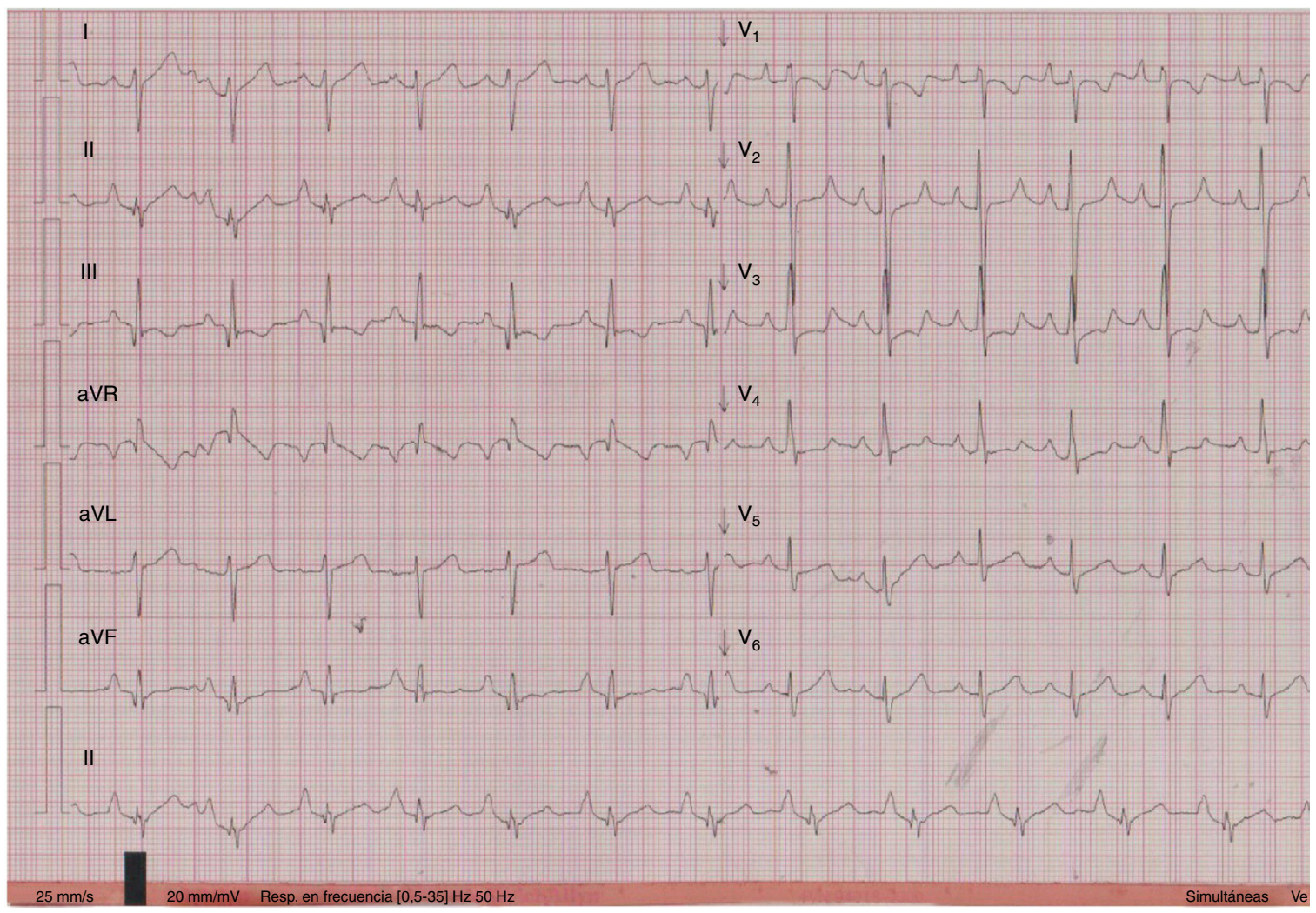

Figura 1 Electrocardiograma de 12 derivaciones en reposo, donde se observa ritmo sinusal con incremento de voltaje en la onda «P» sugestivo de crecimiento de la aurícula derecha. En derivaciones precordiales puede apreciarse un bloqueo incompleto de la rama derecha del haz de His, con eje del QRS en el plano frontal de $+120^{\circ}$. El segmento ST se observa plano y con onda T acuminada con base amplia. El intervalo PR prolongado con $220 \mathrm{~ms}$ sugiere bloqueo AV de primer grado. El intervalo QTm $400 \mathrm{~ms}$ y QTc $473 \mathrm{~ms}$, en límites superiores para la edad. 


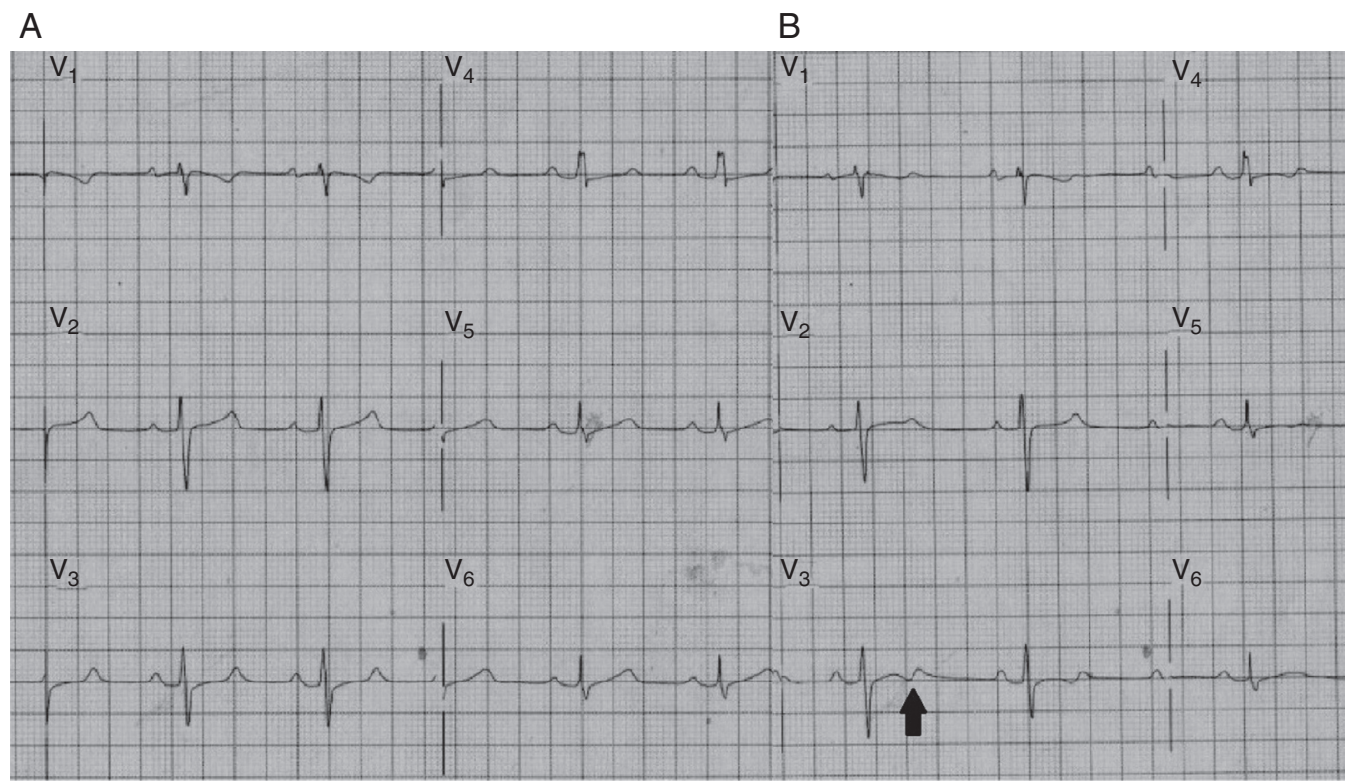

Figura 2 A) EKG basal con QTC $438 \mathrm{~ms}$, con bloqueo AV de primer grado. El segmento ST plano y onda T acuminada con base ancha. B) Al adoptar la posición ortostática incrementa el QTc a 489 ms y se observa cambio en la onda T, adquiriendo un patrón en silla de montar con base ancha sugestivo de QT largo tipo ॥ (flecha).

la amiodarona y la ablación de las vías accesorias ${ }^{2}$. Se puede concluir, por tanto, que la presencia de síndrome de QT largo congénito y su variante con sordera congénita (síndrome de Jervell y Lange-Nielsen) asociados a la anomalía de Ebstein no se encuentran descritos en la literatura.

La prueba de Viskin et al. realizada a esta paciente fue positiva para síndrome de QT largo. Esta prueba ha demostrado ser especialmente útil en los pacientes con QT limítrofe $(440 \mathrm{~ms} \text { a } 480 \mathrm{~ms})^{3}$ como corresponde a este caso.

Un aumento en más de 50 ms del QTc con el máximo estiramiento o frecuencia cardiaca tiene una sensibilidad del $90 \%$ y una especificidad del $86 \%$ para hacer el diagnóstico de SQTL en pacientes con QTc limítrofe ${ }^{4}$. En este caso, el QTc basal fue de $438 \mathrm{~ms}$ y un QTc en el máximo estiramiento de $489 \mathrm{~ms}$, que pudo ser mayor si se tiene en cuenta que ya se encontraba recibiendo tratamiento bloqueador beta con propranolol.

Viskin et al. introdujeron el término «aturdimiento del QT» que hace referencia a la incapacidad de recuperar el QTC basal después de terminado el ejercicio ${ }^{3}$. En la paciente, el QTc basal una vez terminado el ejercicio fue de $467 \mathrm{~ms}$ en comparación con el QTc de $438 \mathrm{~ms}$ antes de la bipedestación.

De acuerdo a los criterios electrocardiográficos postulados por Schwartz ${ }^{5}$, a esta paciente le corresponden 3 puntos por la prolongación de QTC (> 480 ms en la prueba de Viskin), un punto por los episodios sincopales presentados en reposo y medio punto adicional por ser portadora de sordera congénita para un total de 4.5 puntos, lo que en la opinión de los expertos se asocia con una alta probabilidad de síndrome de QT largo congénito6 .

Desafortunadamente no se dispone, en esta paciente, de los resultados del tamizaje genético que tendrían implicaciones en el tratamiento y en la estratificación del riesgo. Actualmente se mantiene estable en tratamiento con bloqueador beta, sin presentar nuevos episodios sincopales.

En conclusión, la asociación de anomalía de Ebstein y el síndrome de QT largo no está descrita en la literatura. La aplicación de los criterios revisados por Schwartz en esta paciente la ubican como un caso altamente probable de SQTL congénito.

\section{Bibliografía}

1. Carpentier A, Chauvaud S, Mace L, et al. A new reconstructive operation for Ebstein's anomaly of the tricuspid valve. J Thorac Cardiovasc Surg. 1988;96:92-101.

2. Derejko P, Wlaczak F, Szumowski L, et al. Ventricular fibrillation in a patient with three accessory pathways, Ebstein anomaly and intermittent long QT interval. RF ablation and electrophysiologic considerations. Kardiol Pol. 2006;64:339-43.

3. Viskin S, Postema P, Bhuiyan Z, et al. The response of the QT interval to the brief tachycardia provoked by standing: A bedside test for diagnosing longQT syndrome. J Am Coll Cardiol. 2010;55:1955-61.

4. Krahn A, Yee R, Chauhan V, et al. Beta blockers normalize QT hysteresis in long QT syndrome. Am Heart J. 2002;143:528-34.

5. Schwartz P. The congenital long QT syndromes from genotype to phenotype: Clinical implications. J Intern Med. 2006;259:39-47.

6. Crotti L, Celano G, Dagradi F, et al. Congenital long QT syndrome. Orphanet J of Rare Dis. 2008;3:18.

Daniel Hurtado-Sierra* y Leonardo Rivera-Rodríguez

Departamento de Cardiología Pediátrica, Instituto Nacional de Cardiología Ignacio Chávez, Ciudad de México, México 
* Autor para correspondencia. Juan Badiano 1, Colonia Sección 16, C.P. 14080, Ciudad de México, México. Teléfono: (+52) (55) 5573 2911, Extensión: 1400, Fax: +52 5554851568 .

Correo electrónico: meddani@hotmail.com

(D. Hurtado-Sierra). http://dx.doi.org/10.1016/j.acmx.2016.04.009

1405-9940/

(c) 2016 Instituto Nacional de Cardiología Ignacio Chávez. Publicado por Masson Doyma México S.A. Este es un artículo Open Access bajo la CC BY-NC-ND licencia (http: / /creativecommons.org/ licencias/by-nc-nd/4.0/).

\section{Successful transradial antegrade recanalization of a chronic total occlusion of an anomalous circumflex artery arising from the right sinus of Valsalva}

\section{Revascularización anterógrada exitosa mediante acceso radial de una oclusión total crónica en una arteria circunfleja con origen anómalo en el seno derecho de Valsalva}

Dear Editor,

Primary congenital anomalies of the coronary arteries are rather rare with an incidence of $0.3-1.6 \% .^{1}$ Anomalous origin of the left circumflex (LCX) coronary artery from the right sinus of Valsalva is the most common congenital coronary variant, with prevalence at coronary angiography of $0.18-0.67 \% .^{2,3}$ Percutaneous coronary intervention ( $\left.\mathrm{PCl}\right)$ for an anomalous coronary artery is a technically challenging and complicated procedure. We report a very unusual case of an anomalous origin of a chronically occluded LCX artery arising directly from the right sinus of Valsalva that was successfully performed by transradial (TR) antegrade approach.

A 66-year-old female with a past medical history of hypertension presented with an 8-month history of exertional chest pain. An echocardiogram showed normal heart wall movement with normal left ventricular ejection fraction. She exercised for $8 \mathrm{~min}$ on the standard Bruce protocol and experienced chest pain, and was found to have a 2-mm ST-segment depression in the inferolateral leads at the end of exercise. After obtaining an informed consent, coronary angiography revealed absence of the left main coronary artery, accompanied with the left anterior descending coronary artery without significant obstructive atherosclerotic lesions (Fig. 1A) and an anomalous origin of a proximal chronically occluded LCX artery from right sinus of Valsalva with a retro-aortic course with the right coronary artery (RCA) and the LCX sharing a common ostium (Fig. 1B). It was a tapered chronic total occlusion (CTO) in the proximal portion of the anomalous LCX with bending $>45$ degrees detected within the CTO segment and $>20 \mathrm{~mm}$ occlusion length $($ JCTO score $=2) .{ }^{4}$ The CTO revascularization was performed from the right radial artery. Before the procedure, the patient was taking clopidogrel $(75 \mathrm{mg} /$ day) and aspirin $(100 \mathrm{mg} /$ day $)$ and during the procedure, received anticoagulation with unfractionated heparin $(70 \mathrm{UI} / \mathrm{kg})$ to achieve an activated clotting time of 250-300 s. With a
$6 \mathrm{Fr}$ Amplatz right (AR) 1 guiding catheter we made a double-wire antegrade technique, involving placement of a separate Sion ${ }^{\circledR}$ wire (Asahi Intecc, Japan) into the RCA to anchor the guide, followed by wiring of the anomalous LCX with a Pilot ${ }^{\circledR} 150$ wire (Abbott Vascular, Santa Clara, CA, USA) supported by a $1.0 \times 10 \mathrm{~mm}$ Falcon ${ }^{\circledR}$ CTO balloon (Invatec, Roncadelle, Italy). Next, we proceeded with the parallel wire technique with the use of a Pilot $^{\circledR}$ 200 wire. This wire punctured the proximal cap at a different position and was easily advanced to the distal true lumen (Fig. 1C). The occlusion was predilated with a $2.0 \times 20 \mathrm{~mm}$ Emerge $^{\circledR}$ semi-compliant balloon (Boston Scientific, Natick, MA,USA) restoring coronary blood flow. Finally, a $2.75 \times 38 \mathrm{~mm}$ Synergy ${ }^{\circledR}$ (Boston Scientific, Natick, MA, USA) bioabsorbable polymer drug-eluting stent was deployed (Fig. 1D) with a good angiographic result (Fig. 2A), which was confirmed by optical coherence tomography (Fig. 2B) and coronary computed tomography angiogram study after angioplasty (Fig. 2C).

To the best of our knowledge this is the first case presented of successful recanalization of a CTO in an anomalously arising LCX performed by TR antegrade approach. Anomalies of the origin and course of the LCX coronary artery are amongst the most frequently encountered. The anomalous LCX originates from the right coronary cusp, either directly, or as a branch from the RCA and courses behind the aorta to the left part of the atrioventricular sulcus, where it resumes its usual configuration. This anomaly is classified as benign since it is not known to predispose individuals to sudden cardiac death. However, some studies have proposed a higher incidence of atherosclerosis and myocardial infarction in the presence of this anomaly. ${ }^{5}$ Anomalies of the LCX artery pose several potential challenges to the interventional cardiologist. Selection of the appropriate equipment (guiding catheter/wire) assumes greater importance, ranging from successfully engaging the ostium of the anomalous coronary artery with adequate support to advance interventional devices and ultimately, concluding the procedure with minimal exposure to contrast agents and radiation. $\mathrm{PCl}$ on anomalous LCX vessels is technically feasible, with a high procedural success rate when performed by experienced operators. ${ }^{6}$ CTOs successful recanalization in patients with viable myocardium has been shown to reduce symptoms like angina decrease the need for surgery and improve survival. ${ }^{7}$ According to the standard practice of the majority of CTO-dedicated centers and operators, $\mathrm{PCI}$ on CTO are attempted using large guiding catheters and transfemoral approach. The TR approach is a valuable alternative to trans-femoral approach, which has been shown to reduce vascular complications and possibly be associated to a better clinical outcome. ${ }^{8}$ 